held on April 23, contains the text of tho addresses of the two principal speakers, Sir William Alexander and Mr. J. Vaizey, together with a report of the discussion (The Finance of Education. Pp. ii +34. London: 1963. Campaign for Education, c/o Hamilton House, Mabledon Place, London, W.C.1, $1963.2 s .6 d$.$) . Both speakers$ strongly urged a reduction in the number of education authorities from the present 146 to about 50, each with a population of about one million, but the discussions emphasized that there was no single answer to the problem of educational finance and that some of the proposals now being canvassed have disadvantages or dangors. Sir William Alexander pointed out that expenditure on education was increasing at the rate of about 9 per cent per annum and was already 4.9 per cent of the national product, while productivity was increasing by only about 2.5 per cent, and he did not think the present system could stand the strain of the next two decades. He thought a percentage grant system relating the contribution by the central Government directly to the expenditure that a local authority incurred on the education service was essential; howover, he did not think that the financial problem could be considered by itself. Further, it was nocessary to consider what was the highest proportion of the gross national product that Britain could invest in education without dotriment to the national oconomy, and the total manpower she could invest in teaching without detriment to increased growth. Such fundamental questions required consideration by an independent commission. Mr. Vaizey suggested that theso fundamental questions wore more for consideration by the profession itself than by a Royal Commission, and he looked for the association of teachers with such develop. ments just as the medical profession was associated with the National Health Service. While he welcomed the increased concern of the central Government with education and thought that the crucial question in tho finance of education (in which higher education represented an increasing proportion) was the future of the rates as an educational tax, ho stressed the importance of regional bodies. Prof. Bondi agreed as to the extent to which innovation and experiment came from the periphery, not from the centre.

\section{Educational Statistics for Britain}

THE second volume of the educational statistics for 1962 has recently been published by the Ministry of Education (Statistics of Education, Part 2, 1962. Pp. 115. London: H.M.S.O., 1963. 20s. net). The topics dealt with include Genoral Cortificate of Education examinations, further education and teacher training (excluding, however, the universities), scholarships and awards, the school health servico, school meals and milk, and educational building. As regards Advanced Level examinations for the General Certificate of Education, it is interesting to note the increasing number of candidates offering economics at that examination. During the past decade the number has increased from about 900 to 5,000. 'There are also considerable increases in the number of candidates passing science and mathematics; the number of girls passing these subjects has increased faster than the number of boys, but the disproportion still remains very groat, except in the biological sciences. In the science group, mathematics passes have increased most in the past decado, and passes in the biological sciences least. Tho further education section contains figures on the colleges of advanced technology, containing 4,800 students on full-timo, and a further 6,200 on sandwich courses. The statistics on students completing teacher training in 1961-62 are affected by the introduction of the three-year course in training colleges; of 7,700 qualifying in that year 3,400 were graduates, a figure which has not changed significantly during the past three yoars. The section on awards makes it possible to obtain some idea of the wastage rate of university students; of the local authority award holders 13.3 per cent of the mon and 12 per cent of the women were classed as premature terminations, and a further 4.9 por cont of the men and 4.0 per cent of the women failed their final examination, thus indicat. ing that just less than one in five of undergraduate award holders fails to complete his or her course satisfactorily.

\section{Scientific Research in British Universities and Colleges,} 1962-63

THE 1963 edition of Scientific Research in British Universities and Colleges contains brief notes on scientific research in progross in British universities and colleges, and describes the nature of the projects in sufficient detail to indicato the scope of the rosoarch done by the various scionce departments and individual teams of investigators. The social scionces and industrial administration are not included except whore work in these fields normally occurs within the science faculty or technology department. Information is supplied for 76 univorsity colloges, institutes and medical schools, and 48 colleges of tochnology. Each university, college, etc., is divided up under subject headings giving staff, their qualifications and fields of research. A name index and a subject index are provided, also a list of addresses of the various universities and colleges, including telephone numbers. Immediate referenco to any name or aspect of research is given by means of a duplex code system. The publication is sponsored by the Department of Sciontific and Industrial Research undor an arrangement with the British Council (1962-63. Pp. xxvi+670. London: H.M.S.O., 1963. 32s. 6d. net).

\section{The Belgian University Foundation}

TuE forty-second annual report of the Belgian Univer. sity Foundation covering the year ended September 30, 1962 , records twenty-four grants to postgraduate students during the year totalling 590,000 franes, subsidies to publications of some 2.8 million francs, of which $2 \cdot 3$ million francs were for periodical publications, and grants to scientific societies totalling 896,000 franes (Pp. 152. Brussels: Fondation Universitaire, 1963). It includes also the twenty-third annual report of its Bureau of Statistics, which gives the number of students in 1961-62 as 32,726 , of whom $19 \cdot 7$ per cent were women. The largest number of students were in the University of Louvain, and 13.47 per cent of the total were in science, $25 \cdot 16$ per cent in medicine, pharmacy and related fields, 12.16 per cent in applied science, 13.17 per cent in commercial science, and 6.01 per cent in social, political or economic science. The report also deals with tho prizes awarded by the Foundation, conferences and reunions held under its auspices, the centre for scientific societies and documentation services which it supports, including an index of periodicals, and lists twenty-six fellowships awarded for 1962-63 by the Belgian American Educational Foundation, as well as of bursaries. Notes are included on the activities of the various other institutions with which the Foundation has particular relations.

\section{The Journal of the Association of Public Analysts}

ANAlysts, consultants and chomists employed in the food and drugs industries will welcome the appearance of the quarterly Journal of the Association of Public Analysts (1, No. 1. Pp. 1-24. London: Association of Public Analysts, 1963, Anuual subscription, 30s.). It is intended that this new journal will include analytical and technical contributions, correspondenco, reports on legal matters and the Association's views on food standards. The first issue includes the following papers: "Dotoction of Insecticide Residues in Fruit and Vegetables", by P. S. Hall; "Determination of Chlorinated Pesticide Residues", by J. A. Potter; "Differentiation of Canned Procossed and Canned Garden Peas", by A. Houlbrooke; "Analytical Data for Grapefrult Juico", by J. G. Sherratt and 